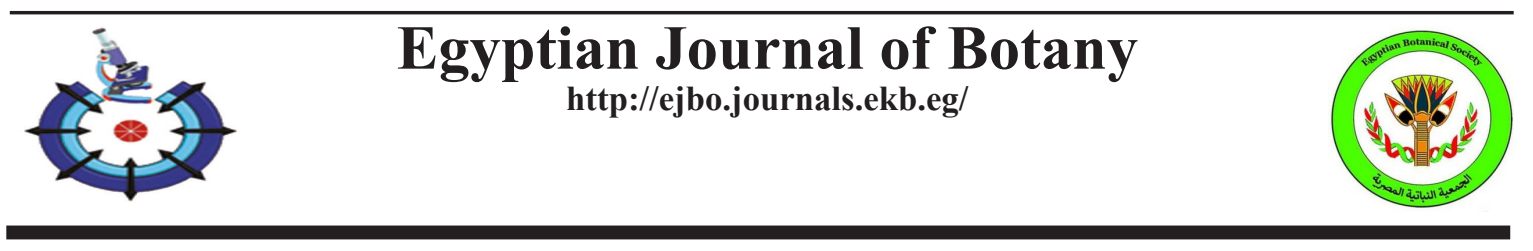

\title{
The Taxonomic Significance of Gross Morphology, Indumentum and Cellular Inclusions in Solanum L. (Solanaceae)
}

\author{
Adel El-Gazzar ${ }^{\#}$, Nashwa A. Moustafa \\ Department of Botany and Microbiology, Faculty of Science El-Arish University, N. \\ Sinai, Egypt.
}

\begin{abstract}
COLANUM is the largest genus in the Solanaceae whose arrangement into infra-generic taxa remained controversial for more than 150 years. A total of 41 characters of leaf morphology, distribution of spines, hair types and crystalline cell inclusions in floral and vegetative parts were recorded for a sample of 51 species of Solanum and Lycianthes rantonnetii. The data matrix was subjected to numerical analysis under 56 combinations of seven dissimilarity measures and eight clustering methods to select the dendrogram which best reflects the relationships among the species in terms of the recorded data. Solanum is divisible into two main groups which correspond roughly to the two traditional subgenera Leptostemonum and Archestemonum. The group resembling Leptostemonum takes in all the species with 3-lobed, shallowly or deeply dissected, partially pinnate, pinnate and bi-pinnate leaves with maximum blade incision index from $27 \%$ to $100 \%$, whereas the group comparable with Archestemonum comprises all the species with only simple leaves and maximum incision index ranging between $0 \%$ and $18 \%$. Of the 25 species in the former group, 20 are woody herbs or shrubs furnished with sharp spines on at least the stem, leaf petioles, leaf veins or the persistent calyx or a combination of two or more of these parts; most members of the latter group are spineless. Separation of Lycianthes rantonnetii from Solanum is not supported by the present study. Epidermal hairs and crystalline cellular inclusions have little distinctive value for groups and subgroups of Solanum.
\end{abstract}

Keywords: Classification, Lycianthes, Lycopersicon, Numerical analysis, Solanum.

\section{Introduction}

Solanum is the largest genus of Solanaceae, comprising $1250-1700$ species or ca. $70 \%$ of the species in the family (Stevens, 2001 onwards). It is a cosmopolitan genus, with the chief center of distribution in Central and South America although numerous species were introduced into widely separated new localities mainly for economic purposes. While a large number of the species are highly prized for their medicinal and ornamental values, the potatoes, tomatoes and aubergins are among the most important vegetable crops worldwide.

The taxonomic history of Solanum is rich with different arrangements of the vast array of species into infra-generic groupings (e.g. Bentham \& Hooker, 1876; Wettstein, 1897; Bitter, 1919a; Seithe, 1962; Danert, 1970; Gilli, 1970; D'Arcy, 1979, 1991; Nee, 1999; Child \& Lester, 2001; Hunziker, 2001; Bohs, 2005). These arrangements are characterized by the tendency of different authors to attach classificatory and phylogenetic significance to different characters and character types. Distinction between infra-generic taxa in traditional classifications of Solanum was based almost exclusively on single morphological characters or rarely on combinations of few characters (e.g. presence of spines, epidermal hair types and anther shape and mode of dehiscence) which, with the exception of the molecular data of Bohs (2005) and Weese \& Bohs (2007), were never recorded comparatively for these taxa.

\#Corresponding author email: elgazzar_adel@hotmail.com

Received $11 / 07 / 2020$; Accepted 29/05/ 2021

DOI: $10.21608 /$ ejbo.2021.35429.1519

Edited by: Dr.: Salama A. Ouf, Faculty of Science, Cairo University, Giza 12613, Egypt.

C2021 National Information and Documentation Center (NIDOC) 
The circumscription of Solanum was equally controversial. The controversy was mainly concerned with whether to treat Cyphomandra, Lycianthes, Lycopersicon, Normania, Nycterium and Triguera (among others) as separate genera or to submerge some or all of them into Solanum. Thus, Miller (1768) established the genus Lycopersicon on seven Solanum species (S. galena, S. lycopersicum, S. aethiopicum, $S$. pimpinellifolium, S. peruvianum, S. procumbens, S. tuberosum). This separation was not in accord with the more recent evidence from cpDNA sequence data (Spooner et al., 1993; Bohs, 2005) and rDNA (Komarova et al., 2008), which suggested the return of Lycopersicon to its initial status within Solanum.

Similarly, Wettstein (1897) regarded Solanum and Cyphomandra as sufficiently different to be widely isolated in two separate groups of the Solaneae (Solaninae and Mandragorinae, respectively). The ca. 50 Cyphomandra species are traditionally distinguished from Solanum by being trees or large shrubs, absence of the poricidal anther dehiscence and having much larger chromosomes. Submerging Cyphomandra into Solanum was later provisionally suggested by Spooner et al. (1993). Contrary to this idea, Bohs (1994) maintained Cyphomandra as a separate genus but soon afterwards (Bohs, 1995) she accepted the union of both genera into Solanum s.l. and validated this union with the required nomenclatural changes. This merger was subsequently corroborated by $n d h \mathrm{~F}$ sequence data which established that Cyphomandra is neatly nested among the major clades of Solanum (Bohs, 2005). However, a more recent study by Bohs (2007) of a larger sample of Cyphomandra species together with some representatives of Solanum seemed to indicate a clear distinction between the two genera based on ITS sequence data and supported by records of self-incompatibility.

Solanum lycioides was established by Linnaeus (1767), maintained (together with a few other species) as Solanum-subsection Lycianthes by Dunal (1852), and as Solanum-section Lycianthes by Wettstein (1897), until it was monographed as a distinct genus Lycianthes (Dunal) Hassler by Bitter (1919b). Subsequent molecular data (Bohs \& Olmstead, 1997; Olmstead \& Palmer, 1997; Olmstead et al., 1999) supported this separation. Additional support for this separation came from sequencing three genes ( $n d h \mathrm{~F}, \operatorname{trn} \mathrm{T}-\mathrm{F}$ and waxy) by Bohs (2005) and Weese \& Bohs (2007) who showed that representatives of Lycianthes, which share the poricidal dehiscence of anthers with Solanum, are phylogenetically closer to those of Capsicum, Witheringia and Physalis than to the Solanum-Cyphomandra assemblage.

While Normania Löwe (with only two rare species: N. triphylla and N. nava endemic to the Macaronesian islands) was included by Wettstein (1897) in Solanum, morphological data and results of scanning electron microscopy of seeds and pollen prompted Francisco-Ortega et al. (1993) to consider it as a distinct genus. Solanum attained its widest concept when Bohs \& Olmstead (2001) included Normania and another monotypic genus (Triguera osbeckii) into it, although relationships of the Normaniaclade encompassing these two genera to other infra-generic clades of Solanum were not decisively resolved. Almost simultaneously, Hunziker (2001) disbanded this widest concept of Solanum s.l. into six individual genera (Solanum s.s., Cyphomandra, Lycopersicon, Lycianthes, Triguera and Normania) to form the Solaninae as one of two major generic assemblages of the Solanaceae. Later, confirmation of separating Normania from Solanum was presented by Bohs (2005).

The different views concerning the relationships between Solanum and its close relatives reflected repeatedly an unresolved conflict between the schemes based on purely morphological attributes and those based on molecular data. While molecular data were recorded comparatively for the taxa investigated and analyzed by relatively sophisticated computer programs, morphological features were consistently used either singly or in combinations of very few characters to take critical taxonomic decisions. A preliminary taxonomic study of the Solanaceae (El-Gazzar et al., 2009) showed that unlike the relative uniformity in some key floral features in Solanum s.l., vegetative morphology was a much richer source of taxonomically useful information which was not put to any practical taxonomic use. Apart from a few studies involving the numerical analysis of variation in floral and vegetative morphology (e.g. Heiser et al., 1965; Abou-El-Enain, 1995), the wealth of data on foliar features and a wide range of microscopic details in the floral parts of Solanum s.l. seems to have been largely overlooked. 
In view of the major discrepancies in the taxonomic treatments of Solanum and its close relatives and the as yet untapped resource of morphological and structural variation, we embarked upon the present study to combine as many of these characters as possible in a numerical analysis in the hope that the result might shed some new light on the taxonomy of this vast and economically important genus.

\section{Material and Methods}

A cosmopolitan sample of fresh and herbarium specimens of 51species of Solanum and Lycianthes rantonnetii (Carrière ex Lesc.) Bitter was assembled together from various sources as given in Appendix 1. Identification of all specimens was re-checked with the aid of appropriate local and regional floras (e.g. Andrews, 1956; Rick, 1977; Feinbrun-Dothan, 1977, 1978; Hunziker, 1979; Zhang Zhi-Yun et al., 1994; Hepper, 1998, 2002; Stevens et al., 2001; Knapp, 2013; Knapp \& Vorontsova, 2016; Vorontsova \& Knapp, 2016; Särkinen et al., 2018; Knapp et al., 2019). The number of specimens examined for each species ranged from one (for S. barbisetum, $S$. capsiciforme, S. ellipticum, S. eremophilum, S. jasminoides, S. parishii and S. umbelliferum) to more than 50 (for $S$. americanum, S. nigrum, $S$. tuberosum and L. esculentum). A list of the 41 characters covering variation in gross morphology, foliar indumentum and the distribution of oxalate crystals and crystal sand in vegetative and floral parts is given in Table 1.

TABLE 1. List of the 41 characters recorded comparatively for 51 Solanum species and Lycianthes rantonnetii and subjected to numerical analysis

1 Plant: woody $1 /$ herbaceous 0

Plant: glabrescent or sparingly hirsute 1/ greycanescent to white-tomentose 0

3 Subterranean tubers: present $1 /$ absent 0

4 Spines on stem: present $1 /$ absent 0

5 Spines on leaf petiole: present $1 /$ absent 0

6 Spines on leaf veins: present $1 /$ absent 0

7 Spines on calyx: present $1 /$ absent 0

8 Simple leaves: present $1 /$ absent 0

9 Shallowly lobed leaves: present $1 /$ absent 0

10 3-many deeply lobed and laciniate leaves: present $1 /$ absent 0
Interruptedly pinnate or bipinnate leaves: present $1 /$ absent 0

12 Leaf blade: length/width ratio*

13 Minimum blade incision percentage (BIP)*

14 Maximum blade incision percentage (BIP)*

15 Leaf blade: flat $1 /$ plicate 0

16 Leaf margin: entire 1/ toothed $2 /$ undulate $3 * *$

17 Base of lamina: cordate-rotundate $1 /$ decurrent 0

18 Leaf apex: acute $1 /$ obtuse 0

19 Petiole/blade length ratio*

20 Inflorescence: terminal $1 /$ axillary or extraaxillary 0

21 Inflorescence: umbel $1 /$ panicle 0

22 Petals (or petal limbs): white $1 /$ yellow $2 /$ pale violet-blue $3^{* *}$

23 Calyx teeth: equal $1 /$ unequal 0

24 Web between calyx teeth: present $1 /$ absent 0

25 Anthers: spherical 1/ cylindrical 0

26 Style: hairy $1 /$ glabrous 0

27 Simple eglandular hairs on leaves: present 1/ absent 0

28 Branched or stellate hairs on leaves: present 1/ absent 0

29 Glandular hairs on leaves: present $1 /$ absent 0

30 Druses in leaf mesophyll: present $1 /$ absent 0

31 Prismatic crystals in leaf mesophyll: present 1/ absent 0

32

Crystal sand in leaf mesophyll: present 1 / absent 0

33 Simple eglandular hairs on calyx: present 1/ absent 0

34 Glandular hairs on calyx: present $1 /$ absent 0

35 Branched or stellate hairs on calyx: present 1/ absent 0

36 Crystal sand in calyx: present $1 /$ absent 0

37 Simple eglandular hairs on petals: present 1/ absent 0

38 Glandular hairs on petals: present $1 /$ absent 0

39 Branched or stellate hairs on petals: present $1 /$ absent 0

40 Fruit surface: hairy 1/ glabrous 0

41 Fruit colour: yellow-bright red 1/ deep purple41 black 0

*= Quantitative character; $* *=$ Multistate character; all others are qualitative (or 2-state) characters. 
Leaf morphology was accurately expressed by: (i) Calculating the maximum blade length/ width ratio, (ii) Shapes of blade apex, margin and base, (iii) Calculating the percentage of petiole to blade length ratio, and (iv) Calculating the blade incision percentages (BIP) and recording the maximum and minimum values for every species. BIP was calculated as:

$\mathrm{BIP}=100-(100 \mathrm{X} / \mathrm{Y})$

where $\mathrm{X}$ is the distance between the bottom of the deepest sinus and the midrib, and $\mathrm{Y}$ is the length of the adjacent lobe from apex to midrib. $\mathrm{BIP}$ is 100 in trifoliolate, pinnate and bipinnate leaves, and 0 in simple leaves with entire margins. The number of mature leaves measured for each species ranged from five to 28 .

As a contribution from the microscopic structural variation between Solanum species, emphasis was laid on epidermal indumentum and crystalline cell inclusions in leaves and sepals. Pieces of dried material were resuscitated in boiling water, bleached in $1 \% \mathrm{KOH}$ and laid in a drop of glycerol on a slide prior to microscopic examination.

The data matrix was subjected to numerical analysis using the seven dissimilarity measures and the eight clustering methods in the program package PC-ORD version 5 for Windows (McCune, 1997); specifications of the program necessitated the abbreviation of species names into only eight digits (see Appendix 1). The resulting 56 dendrograms were shortlisted into only eight by excluding those with excessively high chaining percentages. The procedure set forth by El-Gazzar et al. (2009) and Toto (2009) was adopted whereby the data matrix is rearranged according to the groups in each of the eight dendrograms in order to select that which best reflects the relationships among individual species and between groups in terms of the recorded characters and to extract diagnostic characters of groups at different hierarchical levels.

\section{Results}

The richest sources of taxonomically useful variation in the 52 species included in the present study come from their leaves and calyx. Leaf blades vary considerably from simple with different outlines ranging from linear to broadly ovate (Figs. 1-6), shallowly dissected (Fig. 7-8), deeply dissected (Figs. 9-10), bipinnatisect with obtuse apices of lobes (Fig. 11), bipinnatisect with acute apices of lobes (Fig. 12 \& 13), 3-lobed (Fig. 14), partially pinnate (Figs. 15 \& 16), lacineate with acute apices of lobes (Fig. 17), interruptedly imparipinnate (Fig. 18; only in $S$. tuberosum), and interruptedly imparibipinnate (Fig. 19; only in S. lycopersicum); the terminology of leaf morphology by Stearn (1966) is adopted. These blade shapes were categorized in the data matrix into only the four characters 8-11 in Table 1. While 46 of the species have only one of these types of leaf structure, the remaining six species $(S$. anomalum, $S$. atropurpureum, $S$. dulcamara, $S$. grandiflorum, $S$. wendlandii, and $S$. anomalum) have two or more of them either on the same plant or on different individuals of the same species. Most of the remarkable variety in epidermal hair types described by Seithe (1962) were observed in the 51 Solanum species and were re-defined into only three categories: (i) Simple eglandular, (ii) Simple glandular, and (iii) Branched (including the stalked and sessile stellate forms). Distribution of the three categories on leaves, sepals and petals was recorded in the data matrix. The presence of crystalline cell inclusions in the mesophyll of leaves and calyx in the form of either calcium oxalate (druses and prismatic) or crystal sand was recorded as characters $30-32$ and 36 in Table 1. The list of the 41 characters listed in Table 1 includes 35, 2, and 4 qualitative, multistate and quantitative characters, respectively.

From among the 56 dendrograms resulting from the numerical analysis of the data matrix under various combinations of dissimilarity measures and clustering methods, only that produced by using the combination of Sørensen's similarity measure and Ward's clustering method and illustrated in Fig. 20, was selected for further discussion; the chaining percentage in that dendrogram is $1.95 \%$. A stopping distance level was selected to recognize four groups $\mathrm{C}$ and D (within the main Group A), and E and F (within the main Group B) with their immediate subgroups. The basal assemblages within these four groups are too small to warrant worthwhile taxonomic inferences.

Egypt. J. Bot. 61 , No.3 (2021) 


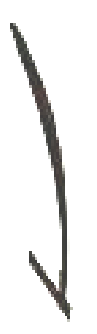

1

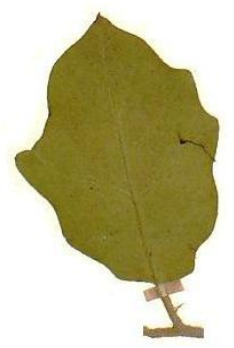

7

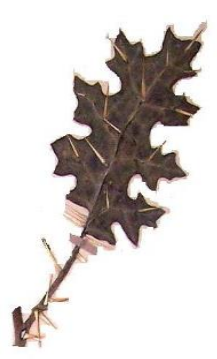

12

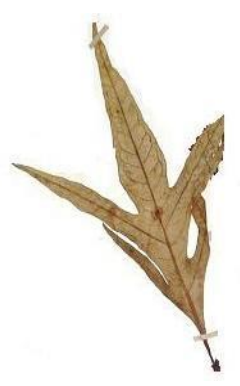

16

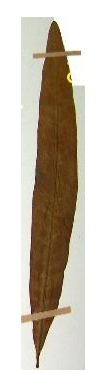

2

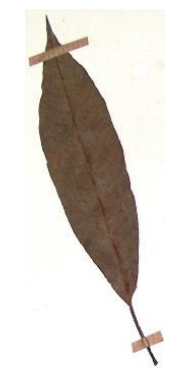

3

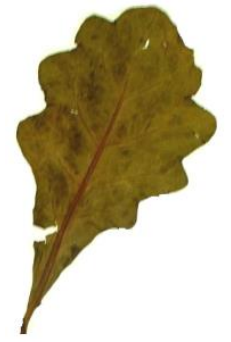

8

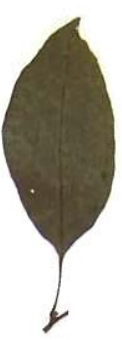

4

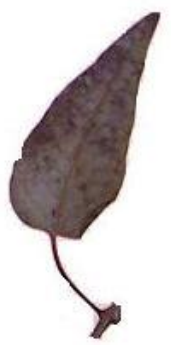

5

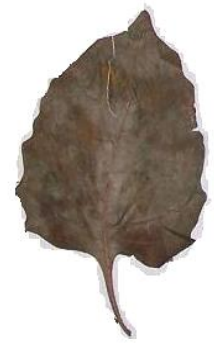

6

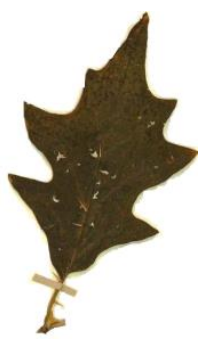

9

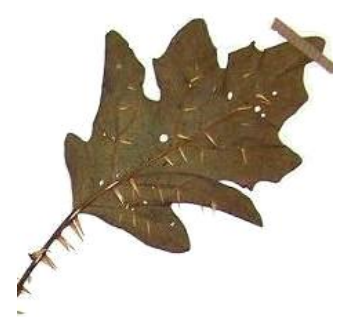

10

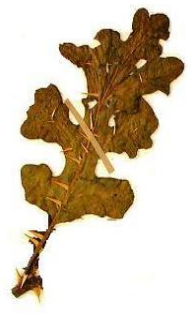

11

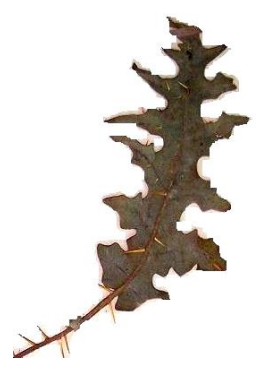

13

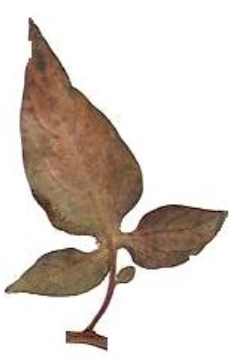

14

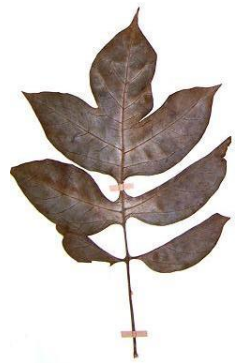

15

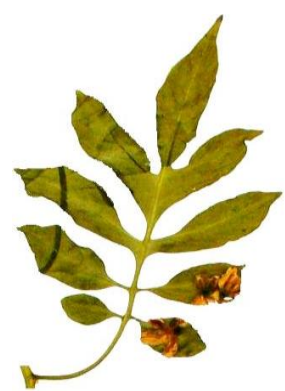

17

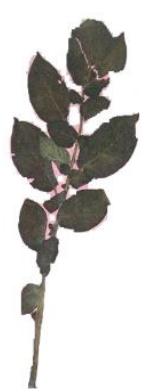

18

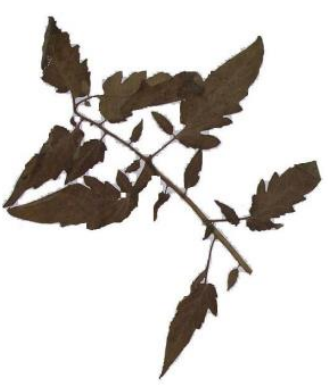

19

Figs. 1-19. Variation in leaf morphology of Solanum. $1=$ Solanum capsiciforme; $2=S$. symonii; $3=$ S. aethiopicum; 4=S. terminale $; 5=S$. jasminoides; $6=S$. villosum; $7=S$. torvum; $8=S$. macrocarpon; $9=S$. anomalum; $10=S$. virginianum $; 11=S$. linnaeanum $; 12=S$. dasyphyllum (bipinnatisect with acute apices); $13=S$. pyracanthos; $14=S$. dulcamara $($ trifoliolate); $15=S$. wendlandii $($ partially pinnate with entire lobes); $16=$ S. laciniatum; $17=S$. seaforthianum (pinnate with opposite leaflets); $18=S$. tuberosum (interruptedly pinnate); $19=S$. lycopersicum (interruptedly bipinnate) [All images are made from herbarium specimens at different scales of magnification] 
SOLANUM

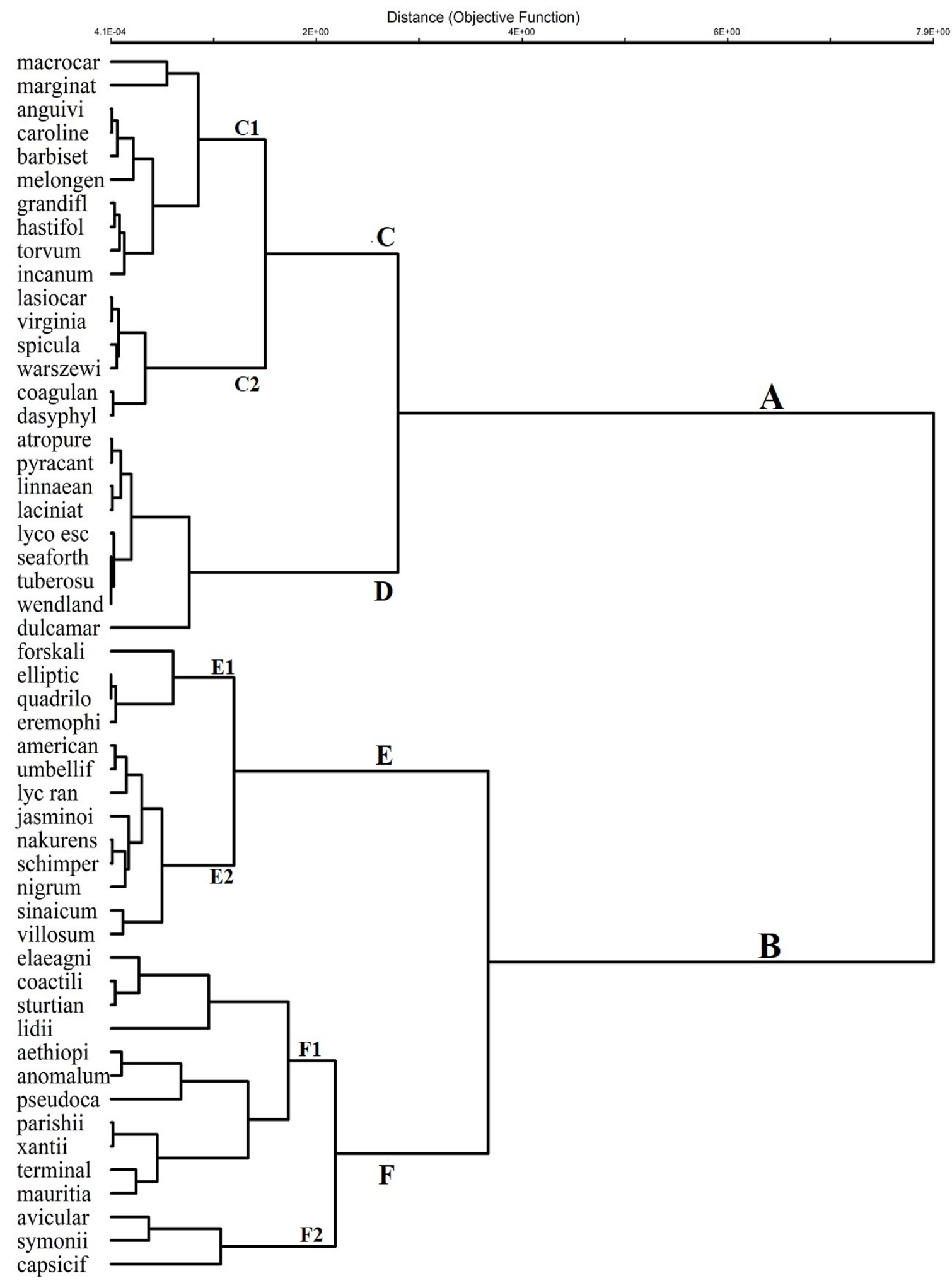

Fig. 20. Dendrogram illustrating phenetic relationships among 51 Solanum species and Lycianthes rantonnetii based on the numerical analysis of 41 characters using the combination of Sørensen'ssimilarity measure and Ward's clustering method [The chaining percentage is $1.95 \%$. Full names of taxa and their abbreviations are given in the Appendix]

Egypt. J. Bot. 61 , No.3 (2021) 


\section{Discussion}

The hierarchical arrangement of the 51 Solanum species and Lycianthes rantonnetii shown in Fig. 20 indicates that they are divisible into two main Groups A and B, and each of the two is further classified into a number of successively smaller groups. Apart from some minor re-allocations of small groups of species in the lower reaches of the hierarchy, Groups A and B produced by four of the numerical analyses of the data matrix performed in the present study are nearly identical despite the radical differences in the algorithms of the Sørensen and the Euclidean dissimilarity (or distance) measures as well as the wide differences in the clustering intensity between the methods of Ward, McQuitty and Flexible $\beta$ used in different combinations in the eight analyses. Likewise, the four subordinate Groups of the two main Groups A and B (Groups A-C, A-D, B-E, B-F) are closely similar in the four analyses, with no less than $90 \%$ similarity between any two corresponding Groups. This is a clear indication of the taxonomic robustness of the two main Groups A and B in Fig. 20 and their subordinate Groups C, D, E, and F.

Among the numerous taxonomic studies of Solanum, the monographic account of the genus by Dunal (1825) remains the most comprehensive to date as he described in great detail and classified no less than 901 individual species and the multitude of their infra-specific taxa. To compare between the results of the present study and previous taxonomic treatments of Solanum, the main Groups and subgroups shown in Fig. 20 are set against the "sections and subsections" in Dunal's traditional classification as well as the phylogenetic schemes of D'Arcy (1979, 1991, 1992), Bohs (2005) and Weese \& Bohs (2007) in Table 2.

It is clear that Dunal's division of Solanum into two major "sections" Leptostemonum and Pachystemonum [equivalent to presentday subgenera] is the closest arrangement to the two main Groups A and B in Fig. 20, respectively. Only four species (S. anomalum, S. ellipticum, S. elaeaganifolium, and $S$. aethiopicum) of section Leptostemonum in Group A have mingled with representatives of section Pachystemonum in Group B. However, the sub-sections of these two sections are widely scattered among the sub-groups of the two major Groups.

Five of the seven subgenera of Solanum recognized by D'Arcy (1991) are represented in Table 2. Species from the largest two subgenera Leptostemonum and Archaesolanum are distributed among the subgroups of Groups A and B. Subgenus Archaesolanum is represented by four species of which one (S. laciniatum) is placed in group A-D, while the other three are aggregated in the small homogenous group B-F2. The larger subgenus Leptostemonum is represented by ten species of which six are in Group A and four in Group B. The two species of subgenus Potatoe (S. seaforthianum, $S$. dulcamara) are confined to Group A-D, while those representing subgenus Minon $(S$. mauritianum, S. pseudocapsicum) fall together in group B-F1; the only representative of subgenus Solanum is placed in group B-E2.

The eight clades recognized by Bohs (2005) and Weese \& Bohs (2007) are represented by 18 species in Table 2 . The eight species representing Clade Leptostemonum are divided into five in Group A and three in Group B. All five species representing Clades Potato and Dulcamaroid are aggregated in Group AD; each of the other five Clades is represented in Table 2 by a single species.

Each of the two main Groups A and B in Fig. 20 and their immediate sub-groups $\mathrm{C}, \mathrm{D}, \mathrm{E}$, and $\mathrm{F}$ is easily separable from its counterpart at the same hierarchical level. Group A accommodates all of the 25 Solanum species with 3-lobed, shallowly or deeply dissected, partially pinnate, pinnate and bipinnate leaves with maximum blade incision index from $30 \%$ to $100 \%$, whereas Group B comprises all 27 species having invariably simple leaves with maximum incision index ranging between $0 \%$ and $18 \%$. The treatment of Solanum lycopersicum as Lycopersicon esulentum seems unjustified since it is deeply immersed in Group AD with its close Solanum relatives having dissected leaves. Similarly, transferring Solanum rantonnetii to Lycianthes (L. rantonnetii) is not supported as it seems inseparable from its simple-leaved close allies in Group BF2. 
TABLE 2. Comparison between groups and subgroups of Solanum in Fig. 20, The traditional classification by Dunal (1825) and the phylogenetic treatments by D'Arcy $(1972,1991,1992)$, Bohs (2005) and Weese \& Bohs (2007). *= Placement according to the website: [https://de.wikipedia.org/wiki/Solanum_subgen_ Archesolanum]

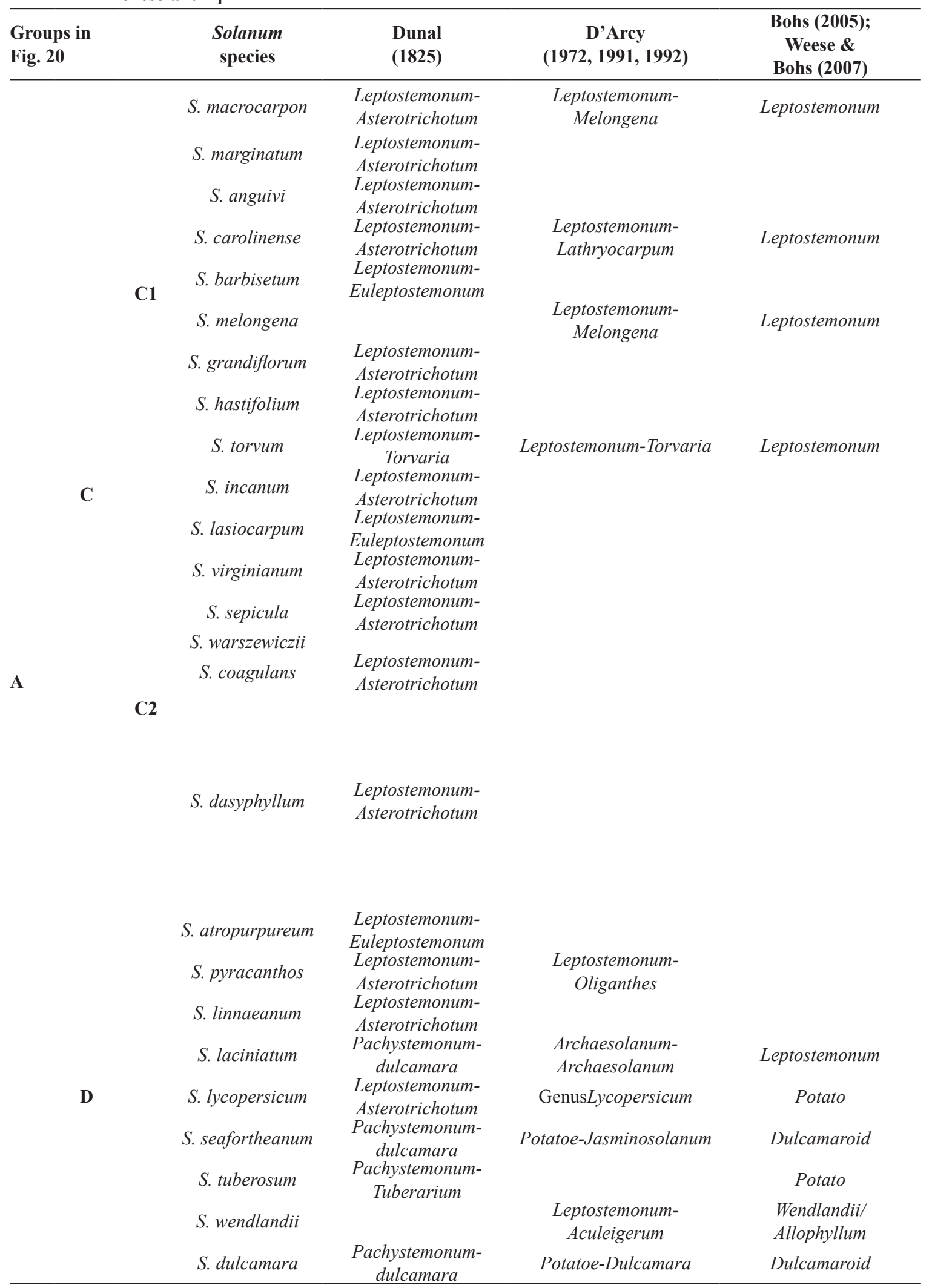

Egypt. J. Bot. 61 , No.3 (2021) 
TABLE. 2. Cont.

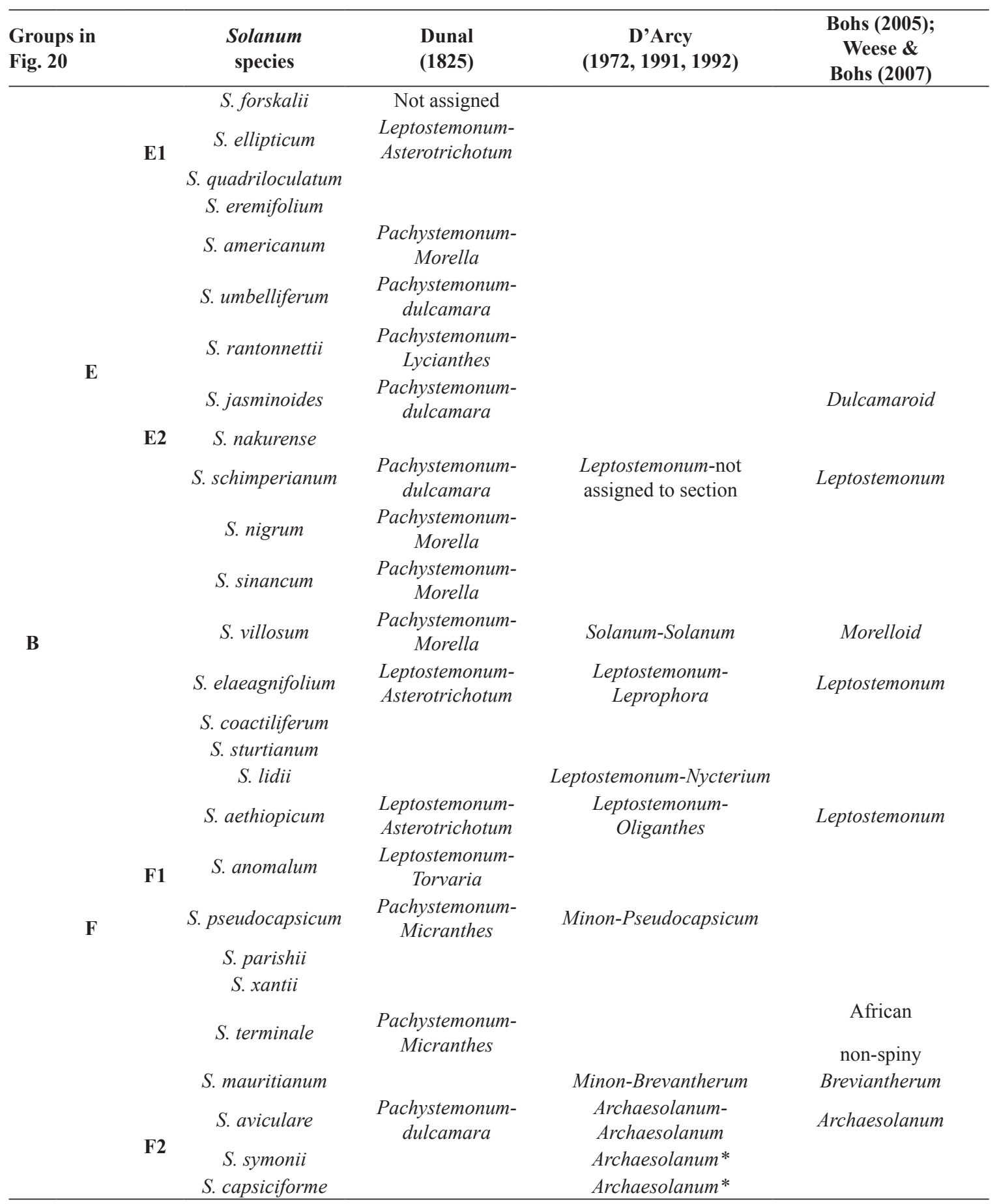

Of the 25 species in Group A, 20 are woody herbs or shrubs furnished with sharp spines on at least the stem, leaf petioles, leaf veins or the persistent calyx or a combination of two or more of these parts; the remaining five species $(S$. laciniatum, $S$. seaforthianum, $S$. wendlandii, $S$. dulcamara, S. tuberosum and S. lycopersicum) are delicate herbs lacking any spines but share dissected or pinnate leaves with the rest of species in Group A. In contrast, 19 of the 27 species in Group B are totally devoid of any spines; the other eight species with spines on any of their four parts are divided equally between Groups B-E1 and B-F1.

The distribution of other characters among 
the 52 Solanum species seems to have little distinctive value for the two main Groups and their subordinate groups. The only exceptions are: (i) All six species in Group A devoid of branched hairs on any of their parts are found in Group $\mathrm{AD}$, and (ii) Out of the 13 species with black ripe fruits, 11 are found in Group B, seven of them in Group BE2.

The sample of 51 species representing Solanum and Lycianthes rantonnetii in the present study is evidently small relative to the enormous size of this much diversified genus. However, using only characters from vegetative and floral morphology, epidermal trichomes and crystalline cell inclusions it was possible to show that the genus is clearly divisible into two easily distinguishable main groups, each of them with two distinct subgroups. A much larger sample of Solanum species, coupled with appropriate representation of such genera as Cyphomandra, Lycianthes and Lycopersicon might be expected to lead not only to a more robust classification of Solanum but also to resolve the long-standing controversy over its relationships with these genera. In 2001, Knapp posed the question "is morphology dead in Solanum taxonomy?". A plausible answer would be: morphology remains a rich source of taxonomically useful characters in Solanum.

Acknowledgements: We wish to thank the Keepers of the herbaria at Cairo University, Alexandria University, the Agricultural Museum in Cairo, and the Orman Botanic Gardens in Giza for permission to inspect herbarium specimens.

Conflicts of interest: No conflicts of interest have been declared.

Authors' contribution: Both authors contributed equally in collecting and identifying the specimens, compiling the data matrix, running the numerical analyses and preparing the article for publication.

Ethical approval: Not applicable

\section{$\underline{\text { References }}$}

Abou-El-Enain, M.M. (1995) Cytotaxonomy of some taxa of the Solanaceae. Ph. D. Thesis, Faculty of Science, Ain Shams University, Cairo. 225p.
Andrews, F.N. (1956) "The Flowering Plants of the Sudan". Vol. 3 (Compositae-Gramineae). T. Buncle \& Co. Ltd., Abroath, Scotland.

Bentham, G., Hooker, J.D. (1876) "Genera Plantarum". Vol. 2(2), 888-889. Reeve \& Co., London.

Bitter, G. (1919a) Die papuasischen Arten von Solanum. Botanischer Jahrbücher, 55, 59-113.

Bitter, G. (1919b) Die Gattung Lycianthes. Abhandlungen Natürwissenschaflichen Vereins Bremen, 24, 292-520.

Bohs, L. (1994) Cyphomandra (Solanaceae). Flora Neotropica Monographs, 63, 1-175.

Bohs, L. (1995) Transfer of Cyphomandra (Solanaceae) and its species to Solanum. Taxon, 44(4), 583-587.

Bohs, L. (2005) Major clades in Solanum based on $n d h \mathrm{~F}$ sequence data. In: "A Festschrift for William G. D'Arcy: The Legacy of a Taxonomist", R.C. Keating, V.C. Hollowell and T.B. Croat (Eds.). Monographs in Systematic Botany from the Missouri Botanical Garden, 104, 27-49.

Bohs, L. (2007) Phylogeny of the Cyphomandra clade of the genus Solanum (Solanaceae) based on ITS sequence data. Taxon, 56(4), 1012-1026.

Bohs, L., Olmstead, R.G. (1997) Phylogenetic relationships in Solanum (Solanaceae) based on $n d h \mathrm{~F}$ sequences. Systematic Botany, 22, 5-17.

Bohs, L., Olmstead, R.G. (2001) A reassessment of Normania and Triguera (Solanaceae). Plant Systematics and Evolution, 228(1-2), 33-48.

Child, A., Lester, R.N. (2001) Synopsis of the genus Solanum L. and its infrageneric taxa. In: "Solanaceae V: Advances in Taxonomy and Utilization", R.G. van den Berg, G.W.M. Barendse, G.M. van den Veerden and C. Mariani (Eds), pp. 3952, Nijmegen University Press, The Netherlands.

Danert, S. (1970) Infragenerische taxa der Gattung Solanum. Kulturpflanze, 18, 253-297.

D'Arcy, W.G. (1979) The classification of the Solanaceae. In: "The Biology and Taxonomy of the Solanaceae", J.G. Hawkes, R.N. Lester and A.D. Skelding (Eds.), pp. 3-47. Academic Press, London. 
D’Arcy, W.G. (1991) The Solanaceae since 1976, with a review of its biogeography. In: "Solanaceae III, Taxonomy, Chemistry, Evolution", J.G. Hawkes, R.N. Lester, M. Nee and N. Estrada (Eds.), pp. 75137. Royal Botanic Gardens, Kew.

D’Arcy, W.G. (1992) Solanaceae of Madagascar: Form and geography. Annals of the Missouri Botanical Garden, 79, 29-45.

Dunal, M.F. (1852) Solanaceae. In: "Prodromus Systematis Naturalis Regni Vegetabilis", A.P de Candolle's (Ed.), Vol. 13, part 1, pp. 29-376. Victor Masson, Paris.

El-Gazzar, A., El-Ghareeb, R., Toto, S.M. (2009) Comparative numerical taxonomy of the Solanaceae. International Journal of Agriculture, Environment and Biotechnology, 2(1), 22-34.

Feinbrun-Dothan, N. (1977) "Flora Palaestina. Part 3, Plates (Ericaceae-Compositae)". Israel Academy of Sciences and Humanities, Jerusalem.

Feinbrun-Dothan, N. (1978) "Flora Palaestina. Part 3, Text (Ericaceae-Compositae)". Israel Academy of Sciences and Humanities, Jerusalem.

Francisco-Ortega, J., Hawkes, J.G., Lester, R.N., Acebes-Ginovés, J.R. (1993) Normania, an endemic Macaronesian genus distinct from Solanum (Solanaceae). Plant Systematics and Evolution, 185(3-4), 189-205.

Gilli, A. (1970) Bestimmungsslüssel der Subgenera und Sektionen der Gattung Solanum. Feddes Repertorium, 81, 429-435.

Heiser, C.B., Sorik, B.J., Burton, D.L. (1965) A numerical taxonomic study of Solanum species and hybrids. The American Naturalist, 99, 471-488.

Hepper, F.N. (1998) Flora of Egypt. Family 159: Solanaceae. Taeckholmia, Additional Series, 6, $1-168$.

Hepper, F.N. (2002) "Solanaceae. In L. Boulos' Flora of Egypt", Vol. 3 (Verbenaceae- Compositae). AlHadara Publishing, Cairo.

Holmgren, P.K., Holmgren, N.H., Barnett, L.C. (1990) "Index Herbariorum, part 1. The Herbaria of the World". Regnum Vegetabile, Vol. 120.
Hunziker, A.T. (1979) The Solanaceae in the neotropics, a critical appraisal. In: "Tropical Botany", K. Larsen and L.B. Holm-Nielsen (Eds.), pp. 355-364. London.

Hunziker, A.T. (2001) "The Genera of Solanaceae". Otto Koeltz, Königstein, Germany.

Knapp, S. (2001). Is morphology dead in Solanum taxonomy? In: "Solanaceae $V$ : Advances in Taxonomy and Utilization", R.G. van der Berg, G.W.M. Brandse, G. van der Weerden and C. Mariani (Eds.), pp 23-38, Nijmegen University Press, Nijmegen, The Netherlands.

Knapp, S. (2013) A revision of the Dulcamaroid clade of Solanum L. (Solanaceae). PhytoKeys, 22, 1-432.

Knapp, S., Vorontsova, M.S. (2016) A revision of the "African Non-Spiny" clade of Solanum L. (Solanum sections Afrosolanum Bitter, Benderianum Bitter, Limurisolanum Bitter, Lyciosolanum Bitter, Macronesiotes Bitter and Quadrangulare Bitter: Solanaceae). PhytoKeys, 66, 1-142.

Knapp, S., Vorontsova, M.S., Särkinen, T. (2019) Dichotomous keys to the species of Solanum L. (Solanaceae) in continental Africa, Madagascar (incl. the Indian Ocean islands), Macaronesia and the Cape Verde Islands. PhytoKeys, 127, 39-76.

Komarova, N.Y., Grimm, G.W., Hemleben, V., Volkov, R.A. (2008) Molecular evolution of 35S rDNA and taxonomic status of Lycopersicon within Solanum sect. Petota. Plant Systematics and Evolution, 276, 59-71.

Linnaeus, C. (1767) "Mantissa Plantarum", 1(2), 4647. Laurentii Salvii, Holmiae.

McCune, B. (1997) PC-ORD version 4, for Windows. Specifications. [http://www.home.centurytel. net/ mjm/winspecs.htm].

Miller, P. (1768) "The Gardeners Dictionary", $8^{\text {th }}$ ed., London.

Nee, M. (1999) Synopsis of Solanum in the New World. In: "Solanaceae IV: Advances in Biology and Utilization", M. Nee, D.E. Symon, R.N. Lester and J.P. Jessop (Eds.), pp. 285-333. Royal Botanic Gardens, Kew.

Olmstead, R.G., Palmer, J.D. (1997) Implications for Egypt. J. Bot. 61, No.3 (2021) 
the phylogeny, classification, and biogeography of Solanum from cpDNA restriction site variation. Systematic Botany, 22, 19-29.

Olmstead, R.G., Sweere, J.A., Spangler, R.E., Bohs, L., Palmer, J.D. (1999) Phylogeny and provisional classification of the Solanaceae based on chloroplast DNA. In: "Solanaceae IV: Advances in Biology and Utilization", M. Nee, D.E. Symon, R.N. Lester and J.P. Jessop (Eds.), pp. 111-137. Royal Botanic Gardens, Kew.

Rick, C.M. (1977) A key to the species of Lycopersicon. Solanaceae News, 4, 11-12.

Särkinen, T., Poczai, B., Barbosa, G.E., van der Weerden, G.M., Baden, M., Knapp, S. (2018) A revision of the Old World Nightshades (Morelloid clade of Solanum L., Solanaceae). PhytoKeys, 106, $1-223$.

Seithe, A. (1962) Die Haararten der Gattung Solanum und ihre taxonomische Verwertung. Botanischer Jahrbücher, 81(3), 261-336.

Spooner, D.S., Anderson, G.J., Jansen, R.K. (1993) Chloroplast DNA evidence for the interrelationships of tomatoes, potatoes, and pepinos (Solanaceae). American Journal of Botany, 80, 676-688.

Stearn, W.T. (1966) "Botanical Latin". Hafner Publishing Co., New York. 566p.

Stevens, P.F. (2001 onwards) Angiosperm Phylogeny Website. Version 9, June 2008. [http://www.mobot. org/MOBOT/research/APweb/]. Visited 30 May, 2018.
Stevens, W.D., Ulloa, U., Pool, A., Montiel, O.M. (2001) (Eds.) Flora de Nicaragua, vol. 3, Angiospermas, Pandanaceae-Zygophyllaceae. Monographs in Systematic Botany from the Missouri Botanical Garden, 85, 1-2376.

Toto, S.M. (2009) Application of numerical techniques to the classification and identification of Solanaceae. M.Sc. Thesis, Alexandria University, Egypt.

Vorontsova, M.S., Knapp, S. (2016) A revision of the spiny solanums, Solanum subgenus Leptosolanum (Solanaceae) in Africa and Madagascar. Systematic Botany Monographs, 99, 1-432.

Weese, T.L., Bohs, L. (2007) A three-gene phylogeny of the genus Solanum (Solanaceae). Systematic Botany, 32(2), 445-463.

Wettstein, R. von (1897) Solanaceae. In: A. Engler and K. Prantl's Die natürlichen Pflanzenfamilien, 4(3a \& 3b): 21-25. Verlag von Wilhelm Engelmann, Leipzig.

Zhang Zhi-Yun, Lu An-Ming, D’Arcy, W.G. (1994) Solanaceae. In: "Flora of China", Wu Zhengyi and P.H. Raven (Eds.), Vol. 17, pp. 300-332. Verbenaceae through Solanaceae, [http://www. efloras.org/browse.aspx?flora id=2]. 


\section{الأهمية التصنيفية للثكل الظاهري وزوائد البشرة والمحتويات الخلوية في جنس السولانم \\ (الفصيلة الباذنجانية) (الفنية) \\ عادل إبراهيم الجزار، نشوى عبد الله مصطفى \\ قسم النبات و الميكروبيولوجي ـ كلية العلوم - جامعة العريش ـ العريش ـ شمال سيناء ـ مصر.}

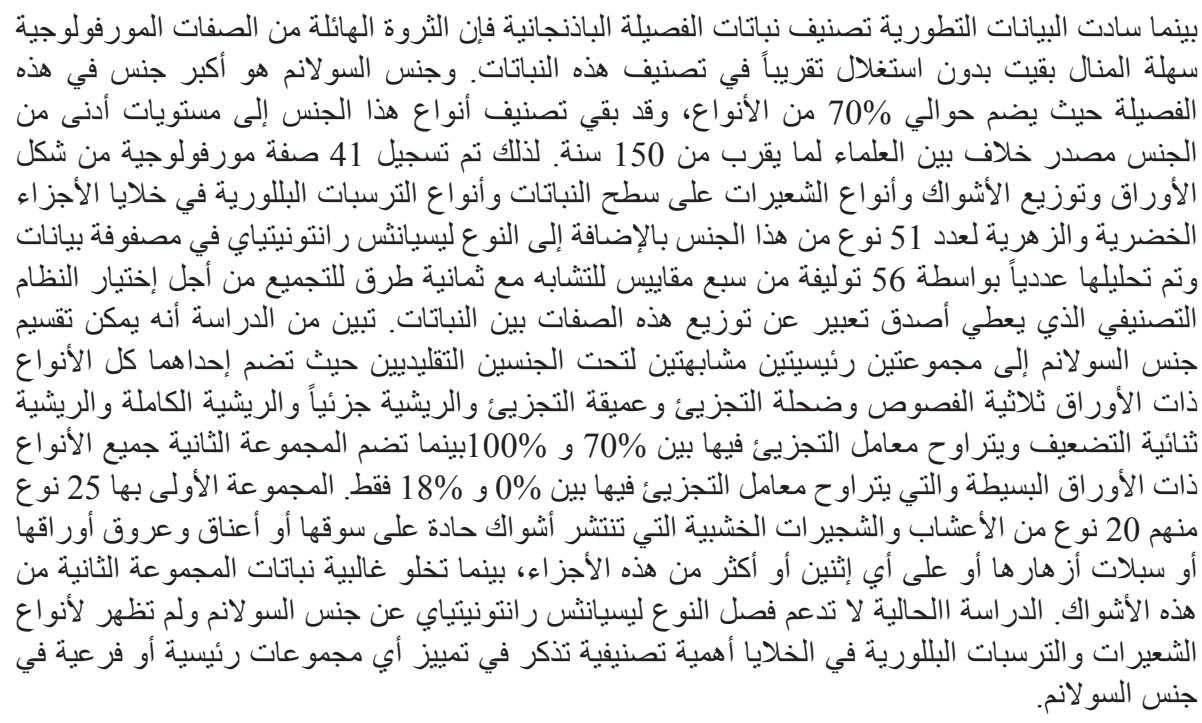

